\title{
Oral Health Status of Hospitalized Children and Parental Perception about Oral Hygiene during Hospi- talization: A Cross Sectional Study
}

\section{Indira MD ${ }^{1}$, Girish $\mathrm{MS}^{2}$, Narayanappa $\mathrm{D}^{3}$}

${ }^{1,2}$ Dept. of Paediatric \& Preventive Dentistry, JSS Dental College and Hospital, JSS AHER, Mysore, India

${ }^{3}$ Dept. of Paediatric, JSS Hospital, JSSAHER, Mysore, India

Correspondence: dr.indiramd@jssuni.edu.in

\begin{abstract}
Background: Oral health is considered as a gateway for general health. Compromised oral health possibly will have a sizeable bearing on the general health status and quality of life. Underlying medical condition in hospitalized children might prevent the care givers to pay attention towards oral health, which can sometimes lead to life-threatening complications. Hence this study was conducted to know status of oral health during hospitalization and perception of parents toward oral hygiene. Methods: An observational cross sectional study was conducted over a period of one month at in patient ward of department of pediatrics. All the subjects were examined for oral health status and their parent's knowledge attitude and practices were assessed through a validated questionnaire. Results: Caries prevalence was high. $42.6 \%$ of children had 1 or more teeth decayed, filled or extracted. The mean dmft /DMFT score was $3.58 \pm 1.75$ and DMFT score was $1.43 \pm 2.51$ overall. There was a significant decrease in the plaque score from the date of admission to date of discharge. Only $42.6 \%$ of the parents of hospitalized children were aware about the oral health status of their wards.

Conclusions: It was found that the parents of hospitalized children were very much aware of importance of oral health. Hence, preventive strategies involving care givers/guardians, with timely reinforcements would help in reduction of caries experience and improvement in gingival/oral health of these individuals
\end{abstract}

\section{Introduction}

Oral health is considered as a gateway for general health. Compromised oral health possibly will have a sizeable bearing on the general health status and quality of life. Medically compromised children are at increased risk of compromised oral health compared to healthier counterparts, which can sometimes lead to life-threatening complications.[1] Though there is a great improvement in the oral health status of medically compromised children is some countries globally it is still poor. Caries risk assessment and Caries risk assessment tools guidelines categorize children with special health care needs as high risk for caries development.[2]

Children and their caretakers often neglect oral health and more so when hospitalized. There are number of factors like change in the environment, stress of hospitalization, development of pathologies, change in the meal, medications, decrease in the host resistance etc., that might have a negative impact on the child during hospitalization. This will have an
Oral health promotion during hospitalization provides a positive impact and is necessary especially for children. The presence of dental surgeon or a pediatric dentist strengthens the medical team in maintaining the integrality of the child patient.[4]

Promotion of oral health in the hospital environment enhancing oral health knowledge, motivating hospitalized children and their parents/ caregivers provides an integral and humanized care for hospitalized children.[5]

The child gets hospitalized with some acute problems and the importance of good dental health during hospitalization is often not realized nor explained to children or their caregivers. When looking from a dental perspective, there are two major problems associated with this: First one is the lack of speciality dental care/expertise for these children in hospital. Second being, unavoidably, the primary focus of attention of parent/caregiver would be focused to medical treatment of their ward. Pediatric Dentist recommends providing special attention to oral 
during hospitalization we the team of Pediatrician and Pediatric dentist conducted a cross sectional study to assess the oral health status of children during hospitalization and evaluate parenteral perception towards oral health of their children during hospitalization.

\section{Methodology:}

Study design:

A cross sectional descriptive study was conducted among the hospitalized children in the pediatric ward during the month of July to December 2019.

\section{Ethical clearance and consent:}

The study was conducted after obtaining the approval from the Institutional Ethical Committee of JSS Medical College Mysuru. Parents were informed about the objective of this study and the consent for participation in the study was obtained by signing the Informed consent form. An assent was also taken from the participating child.

\section{Study population and sampling technique:}

The present study was conducted in Pediatric ward of Dept of Pediatrics, JSS Hospital, Mysuru. Among all the hospitalized children in Pediatric ward during the month of July to December 2019, 338 children who fulfilled the inclusion criteria were included in the study.

Inclusion criteria:

Child aged $5-12$ years.

Children with medically compromised condition ( i.e children with history of cardiac, hematological, renal, gastroenterological and endocrinological disorders, respiratory and neurological diseases)

Child should be hospitalized for minimum of 3 days.

Exclusion criteria:

Special Child

Children with genetic disorder like Down's syndrome etc. Children with $<3$ days of hospital stay.

For the study purpose all the children with previous medical history (like cardiac, hematological, renal, gastroenterological and endocrinological disorders, respiratory and neurological diseases) were categorized as medically compromised and all the children admitted otherwise were grouped as non-medically compromised children. All the children were on the same nutritional regimen during hospitalization. All the children in the study were evaluated for Caries status using dmft /DMFT index and oral hygiene status using Modified Quigley Hein In- breakfast. To assess the caries experience WHO diagnostic criteria calculating the mean def and DMFT was used. Oral examination was done using sterile disposable mouth mirror, sterile gauze, wooden spatula and natural light on the child's bed in the Pediatric ward.

Oral hygiene status was evaluated using Modified Quigley Hein Index on the day of admission and discharge. Two-tone Disclosing agent was used to disclose the plaque; the plaque was quantified and recorded on the day of admission using sterile disposable mouth mirror, sterile gauze and wooden spatula under natural light.

The parenteral perception towards oral health of their children was assessed through the questionnaire. Parents were requested to complete the questionnaire. The questionnaire include 15 questions which were split into three categories covering knowledge about general and dental health, attitude towards professional dental care for their children and oral hygiene practices followed for their children. Before the administration of the questionnaire the content and phase validity was carried out with a cronbach's alpha value of 0.87 .

\section{Statistical Analysis:}

The recorded data were entered onto a personal computer and then transferred to an MS-Excel sheet, and statistical analysis was carried out using Statistical Package for Social Sciences (version 22.0 for Windows, SPSS Inc., Chicago, IL, USA). Considering the statistical significance of $5 \%(p<0.05)$ Pearson's Chi squared test and Mann Whitney tests were used for analytical statistical analysis.

\section{Result:}

The characteristic of study population (Table-1) consisted of 338 children aged 5-12 years with mean age of 8.11 years out of which 148 were medically compromised. In the study population $55.9 \%$ were males and $44.1 \%$ were females. $42.6 \%$ of hospitalized children had dental caries. Less than $50 \%$ of them visited/ received dental treatment. As per the medical records, $72.8 \%$ of the hospitalized children received at least three different types of liquid medication three times day as prescribed by the pediatrician. $57.2 \%$ of hospitalized children performed oral hygiene care. Total length of hospital stay varied from 5-10 days.

Only $57.2 \%$ of the study population performed oral hygiene in the hospital. Among the children who performed oral hygiene only $15.5 \%$ brushed twice daily and 
Table 1: Characteristics of study population

\begin{tabular}{|c|c|c|c|c|}
\hline \multicolumn{2}{|l|}{ Variables } & $\begin{array}{l}\text { Non-medically } \\
\text { compromised } \\
(n=190)\end{array}$ & $\begin{array}{l}\text { Medically com- } \\
\text { promised } \\
(n=148)\end{array}$ & $\begin{array}{c}\text { Total } \\
(n=338)\end{array}$ \\
\hline \multirow{3}{*}{ Gender } & & & & \\
\hline & Male & $99(52.1)$ & $90(60.8)$ & $189(55.9)$ \\
\hline & Female & $91(47.9)$ & $58(39.2)$ & $149(44.1)$ \\
\hline \multirow[t]{2}{*}{ Caries Experience } & Yes & $52(27.4)$ & $92(62.2)$ & $144(42.6)$ \\
\hline & No & $138(72.6)$ & $56(37.8)$ & $194(57.4)$ \\
\hline \multirow[t]{2}{*}{ Previous dental visit } & Yes & $48(25.3)$ & $57(38.5)$ & $105(31.1)$ \\
\hline & No & $142(74.7)$ & $91(61.5)$ & $233(68.9)$ \\
\hline \multirow{2}{*}{$\begin{array}{l}\text { Did the child take liquid } \\
\text { medication during hos- } \\
\text { pitalization }\end{array}$} & Yes & $152(80)$ & $94(63.5)$ & $246(72.8)$ \\
\hline & No & $38(20)$ & $54(36.5)$ & $92(27.2)$ \\
\hline \multirow{2}{*}{$\begin{array}{l}\text { Did the child perform } \\
\text { oral hygiene during hos- } \\
\text { pitalization }\end{array}$} & Yes & $112(58.9)$ & $81(54.7)$ & $193(57.2)$ \\
\hline & No & $78(41.1)$ & $67(45.3)$ & $145(42.8)$ \\
\hline
\end{tabular}

Table 2: Oral hygiene practice by children during hospitalization

\begin{tabular}{|c|c|c|c|c|}
\hline \multicolumn{2}{|c|}{ Variables } & $\begin{array}{c}\begin{array}{c}\text { Non-medically } \\
\text { compromised } \\
(\mathbf{n}=190)\end{array} \\
\mathrm{N}(\%)\end{array}$ & $\begin{array}{c}\begin{array}{c}\text { Medically } \\
\text { compromised } \\
(\mathbf{n}=148)\end{array} \\
\mathrm{N}(\%)\end{array}$ & $\begin{array}{c}\begin{array}{c}\text { Total } \\
(n=338)\end{array} \\
N(\%) \\
\end{array}$ \\
\hline \multirow{2}{*}{$\begin{array}{l}\text { Did the child perform } \\
\text { oral hygiene during } \\
\text { hospitalization }\end{array}$} & Yes & $112(589)$ & $81(547)$ & $193(572)$ \\
\hline & No & $78(41.1)$ & $67(45.3)$ & $145(42.8)$ \\
\hline \multirow{2}{*}{$\begin{array}{l}\text { How many times did } \\
\text { the child brush }\end{array}$} & Once & $88(78.5)$ & $75(92.6)$ & $163(84.5)$ \\
\hline & Twice & $24(21.5)$ & $6(7.4)$ & $30(15.5)$ \\
\hline \multirow[t]{3}{*}{$\begin{array}{l}\text { What was used to } \\
\text { perform oral hygiene } \\
\text { during hospitalization }\end{array}$} & $\begin{array}{c}\text { Tooth brush } \\
+ \text { tooth } \\
\text { paste }\end{array}$ & $102(91.1)$ & $68(83.9)$ & $170(88.1)$ \\
\hline & $\begin{array}{l}\text { Tooth brush } \\
+ \text { tooth } \\
\text { paste }+ \text { floss }\end{array}$ & - & - & - \\
\hline & $\begin{array}{c}\text { Hand/ gauze } \\
\text { + water }\end{array}$ & $10(8.9)$ & $13(16.1)$ & $23(11.9)$ \\
\hline
\end{tabular}

The

mean + water wards. Among them only $24.9 \%$ seek

plaque score on the day of discharge among the nonmedically compromised and medically compromised was $1.8 \pm 0.7$ and $2.1 \pm 0.6$ respectively. The results showed statistically significant difference in the plaque score from the day of admission to the day of discharge in both the groups. (Table 3 )

Caries prevalence was high. $42.6 \%$ of children had 1 or more teeth decayed, filled or extracted. The mean dmft score was $3.58 \pm 1.75$ and DMFT score was $1.43 \pm 2.51$ overall. The mean $\mathrm{dmft}$ score and mean DMFT was more among medically compromised than non-medically compromised children. However there was no statistically significant difference between the scores. . (Table 4)

Parenteral Awareness about Oral Health:

Oral Hygiene Perception of children and parents during Hospitalizatıon

\begin{tabular}{|l|c|c|}
\hline Systemic Health & Mean dmft & $\begin{array}{c}\text { Mean } \\
\text { DMFT }\end{array}$ \\
\hline $\begin{array}{l}\text { Non-medically compro- } \\
\text { mised }\end{array}$ & $3.22 \pm 1.45$ & $1.38 \pm 2.60$ \\
\hline Medically compromised & $3.78 \pm 2.73$ & $1.52 \pm 2.37$ \\
\hline Total & $3.58 \pm 1.75$ & $1.43 \pm 2.51$ \\
\hline Statistical inference & $\begin{array}{c}\text { p value: } \\
.092^{*}\end{array}$ & $\begin{array}{c}\text { p value: } \\
.452^{*}\end{array}$ \\
\hline \multicolumn{2}{|l}{} \\
\hline
\end{tabular}


dental treatment. only $34 \%$ of agree that oral health is equally important as general health and $29.6 \%$ have knowledge that bad oral health affects the general health. (Table 5)

Table 5: Knowledge about oral health among study

\begin{tabular}{|l|c|}
\hline & $\begin{array}{l}\text { Frequency } \\
\mathbf{n = 3 3 8}(\mathbf{\%})\end{array}$ \\
\hline $\begin{array}{l}\text { Does your child suffer from oral dis- } \\
\text { ease? }\end{array}$ & $144(42.6)$ \\
\hline $\begin{array}{l}\text { Have you sought treatment for oral } \\
\text { disease? }\end{array}$ & $84(24.9)$ \\
\hline $\begin{array}{l}\text { Is oral health equally important as } \\
\text { general health? }\end{array}$ & $115(34.1)$ \\
\hline $\begin{array}{l}\text { Does bad oral health affect the general } \\
\text { health? }\end{array}$ & $100(29.6)$ \\
\hline
\end{tabular}

\section{population}

\section{Knowledge regarding plaque and gingival health:}

Regarding knowledge about gingival health $59.4 \%$ of the parents said they had no knowledge about it and $17.5 \%$

\begin{tabular}{|l|l|l|l|}
\hline & $\begin{array}{l}\text { Frequency } \\
(\%)\end{array}$ & $\begin{array}{l}\text { Frequency } \\
(\%)\end{array}$ \\
\hline $\begin{array}{l}\text { What is } \\
\text { dental } \\
\text { plaque? }\end{array}$ & $\begin{array}{l}\text { How to pre- } \\
\text { vent bleed- } \\
\text { ing gums/ } \\
\text { redness of } \\
\text { gingival? }\end{array}$ & \\
\hline $\begin{array}{l}\text { Soft bacterial } \\
\text { deposit on } \\
\text { teeth }\end{array}$ & $51(15.1)$ & $\begin{array}{l}\text { Brushing and } \\
\text { flossing }\end{array}$ & $59(17.5)$ \\
\hline Soft food & $51(15.1)$ & $\begin{array}{l}\text { Consuming } \\
\text { soft food }\end{array}$ & $24(7.1)$ \\
\hline Don't know & $236(69.5)$ & $\begin{array}{l}\text { Taking medi- } \\
\text { cation }\end{array}$ & $54(16.0)$ \\
\hline & & Don't know & $201(59.4)$ \\
\hline
\end{tabular}

said redness of gingiva can be prevented by brushing and flossing. $7.1 \%$ said it could be prevented by consuming soft food and $16 \%$ thought it could be prevented by taking medication. Parenteral knowledge about dental not visiting the dentist $63.5 \%$ said since Primary teeth will fall, treatment was not required, $14.2 \%$ said their child has no pain. $22.3 \%$ felt that taking care of general health was more important than oral health. (Table 7)

\begin{tabular}{|c|c|c|}
\hline & & Overall \\
\hline & & $\begin{array}{l}\text { Frequency } \\
(\%)\end{array}$ \\
\hline \multirow{2}{*}{$\begin{array}{l}\text { Have you taken } \\
\text { your child to den- } \\
\text { tist? }\end{array}$} & Yes & $105(31.1)$ \\
\hline & No & $233(68.9)$ \\
\hline \multirow{2}{*}{$\begin{array}{l}\text { When have you } \\
\text { visited the dentist? }\end{array}$} & $\begin{array}{ll}\begin{array}{l}\text { Child complains of } \\
\text { pain }\end{array} & \\
\end{array}$ & $88(83.8)$ \\
\hline & $\begin{array}{l}\text { When parents notice } \\
\text { some problem }\end{array}$ & $17(16.2)$ \\
\hline \multirow{3}{*}{$\begin{array}{l}\text { Reason for not visit- } \\
\text { ing dentist }\end{array}$} & Primary teeth will fall & $148(63.5)$ \\
\hline & No pain & $33(14.2)$ \\
\hline & $\begin{array}{l}\text { Taking care of gen- } \\
\text { eral health is more } \\
\text { important }\end{array}$ & $52(22.3)$ \\
\hline \multirow{2}{*}{$\begin{array}{l}\text { Do you need infor- } \\
\text { mation about oral } \\
\text { health in hospital }\end{array}$} & Yes & $338(100)$ \\
\hline & No & - \\
\hline
\end{tabular}

\section{Table 7: Attitude towards oral health}

\section{Practice of oral hygiene}

From the study it was found that only $15.5 \%$ of the study population brushed twice daily. $43.4 \%$ only advice to brush and do not involve in child's brushing procedure. $56.5 \%$ insist the child to brush during hospitalization. 49.4

\begin{tabular}{|l|c|}
\hline & Overall \\
\hline & Frequency (\%) \\
\hline Children who brushed twice daily & $30(15.5)$ \\
\hline $\begin{array}{l}\text { Parents who only advice to brush } \\
\text { and do not involve }\end{array}$ & $147(43.4)$ \\
\hline $\begin{array}{l}\text { Parents who insist to brush during } \\
\text { hospitalization }\end{array}$ & $191(56.5)$ \\
\hline $\begin{array}{l}\text { Parents advice the child to drink } \\
\text { water after taking medication }\end{array}$ & $167(49.4)$ \\
\hline
\end{tabular}

$\%$ advice to drink water after taking (Table 8 )

\section{Table 8: Practice towards oral hygiene}

The caries status in the present study is same in both medically and non medically compromised children. 
where the caries score was more in medically compromised children. However we could not retrieve any Indian studies conducted on hospitalized children.

\section{Discussion}

Oral health has been considered as an integral part of general health. Oral health status has great impact on general health and vice versa.[7] Oral health has strong social, biological and psychological prognostications, because it affects esthetics and communication in a child.[7] Oral health care of chronically ill child is often neglected. A pre occupation with principal medical condition often results in the neglect of other facets of child's overall health.[8] Dental disease can negatively affect the success of medical treatment. Patients who are on long term medication would definitely be on liquid oral medications, which would have fermentable carbohydrates [4] and poor salivary flow and buffering capacity as side effects of medications administered for medical conditions [9], which further can have an impact on the caries status of medically compromised children.[10]

In the present study out of 338 children examined 190 children $(56.2 \%)$ were non medically compromised admitted for various reasons and 148 children (43.8\%) were medically compromised. Among the medically compromised $60.8 \%$ were males and $39.2 \%$ were females. $62.2 \%$ of medically compromised children had caries while only $27.4 \%$ of non medically compromised children have caries. (Table 1)

$54.7 \%$ of medically compromised performed oral hygiene during hospitalization and $92.6 \%$ of them brushed only once (Table 2) in spite of consuming oral liquid medication with high cariogenic potential (72.8\%). Previous studies have also shown that the study population does not perform oral hygiene after consuming liquid medication. [4,17] The cariogenic potential of sucrose containing liquid medications along with poor oral hygiene and medically compromised condition increases the risk of developing dental caries.[17-21]

To know the oral hygiene status of oral hygiene, Plaque score of all the children were recorded using modified Quigley Hein index on the day of admission and discharge. The mean plaque score for medically compromised patient was 3.2 when compared to 2.9 of non-medically compromised children on the day of ad- mean plaque score from the day of admission to the day of discharge in both the groups which could be due to rise in care level and also due to interaction with the investigator. (Table 3)

The caries prevalence among the study subject was $42.6 \%$. The mean $\mathrm{dmft}$ score was 3.22 in nonmedically compromised children when compared to mean dmfs of 3.78 of medically compromised children. (Table 4). This may be attributed to the low awareness about oral health among the parents. When the parents of the hospitalized children were assessed for knowledge about oral health through questionnaire it was observed that $42.6 \%$ of the parents were aware of the oral health issues of their wards. Among them only $24.9 \%$ of the parents sought treatment for the oral ailments of their wards. $34.4 \%$ of parents believed that oral health is equally important as general health and $29.6 \%$ of parents were aware of the fact that bad oral health can have its effect on general health of their wards. (Table 5)

$69.5 \%$ of the parents were not aware of knowledge about plaque and $59.4 \%$ of parents didn't know the effects of plaque on gingiva and the ways to avoid gingival bleeding.(Table 6). Some thought it to be a discoloration of tooth, some thought it to be a heavy deposits on the tooth, this was in line with the study conducted by Mahamoud $\mathrm{k}$ alomiri et al. [11]

The attitude and practice towards oral hygiene was equally poor. Only $31.1 \%$ of the parents had taken their ward for dental visit for some treatment or the other. Out of them $16.2 \%$ took their ward to dentist after they noticed that their ward had some oral health issues. Among the parents who had not taken their children to dentist responded by saying that since the teeth were primary, they would shed on their own and hence need no treatment., followed by their ward never experienced any pain was the second most common reason. All the 338 participants in the survey were very eager to enhance their knowledge about oral health care. (Table 8) These findings were concurrent with previous studies where the reasons for poor motivation was the medical condition of their ward which was of primary concern for the parents, But essential motivation to effectively implement the knowledge into deeds is the need of the hour.[12-14] 
their primary oral hygiene tool. oral hygiene tool. It was noticed that $43.4 \%$ of the parents only advised their wards about oral hygiene and never involved with children to have best possible oral health. Around $56.5 \%$ of the parents felt that it is equally important to brush and maintain good oral hygiene even during hospitalization and $49.4 \%$ of parents advised to drink water after consuming medication (Table 8). These findings were in comparable with that of the study done by Al Omiri et al in North Jordan.[11]

In the present study caries experience in both the groups were at a alarming trend, this could be attributed to factors like, medications, diet and inadequate oral hygiene. The poorer gingival/oral health can be due to environmental, systemic and local factors. Obstacles which prevent individual patients in achieving good oral hygiene could be lack of supervision/ assistance. Hence preventive strategies involving care givers/guardians/ community [15], with timely reinforcements would help in reduction of caries experience and improvement in gingival/oral health of these individuals.[16]

\section{Conclusion}

The hospitalized children had precarious oral health condition. The risk factors like compromised medical condition, poor oral hygiene practice and intake of cariogenic potential drugs exposes these children to compromised oral health. Therefore it seems important to have multi professional approach including a pediatric dentist to provide a comprehensive care to hospitalized children.

\section{References}

1. American academy of pediatric dentistry. Clinical guideline on management of persons with special health care needs. Pediatric Dentistry, 2004, 26 (7):77-80.

2. American academy of pediatric dentistry, Caries risk assessment tool. Pediatric dentistry, 2004,26(7):198.

3. Petersen $\mathbf{P}$ et al. The global burden of oral diseases and risks to oral health. Bullet in of the world health organization, 2005,83(9):661-9.

4. Altamirano EHD, Jereissati L. Respiratory physiotherapy and mother/child hospitalization. Psicol blica 2005; 39(2):305-10.

6. Sharma S, Parashar P, Srivastava A, Bansal R. Oral Health Status of 9 To 12 Year Old School Going Children In Urban Meerut. Indian Journal Of Community Health;25(1): 61-65

7. Solanki J, Gupta S, Chand S. Comparison Of Dental Caries And Oral Hygiene Status Among Blind School Children And Normal Children, Jodhpur City Rajasthan India. Universal Research Journal Of Dentistry 2014; 4(1):22-25

8. Cetinguc A, Tekcick M, Gunor H C. Oral Health Status Of Medically Compromised children referred for dental consultations: A Retrospective Study. Hacettepe Dentistry Faculty Journal. 2004; 28( 3):41-45

9. Leone C W, Oppenheim F G, Physical And Chemical Aspects Of Saliva As Indicators Of Risk For Dental Caries In Humans. Journal Of Dental Education, 2001, 65(10):1054-62

10. Sahagal J, Sood P B, Raju O S. A Comparison Of Oral Hygiene Status And Dental Caries In Children On Long Term Liquid Oral Medications To Those Not Administered With Such Medications. J Indian Soc Pedo Prev Dent. 2002; 20(4):144-151.

11. Mahamoud k alomiri et Al. Oral Health Attitudes, Knowledge and Behaviour Among school children in North Jordan. Journal of Dental Education 2006; 70 (2); 179-85.

12. Grahn K, Wilkstrom S, Nyman L, Rydberg A, Stecksen-Blicks C. Attitudes about dental care among parents whose children suffer from severe congenital heart disease: A Case - Control Study. Int J Pediatric Dent 2006;16:231-38

13. Saunders CP, Roberts GJ, Dental Attitudes, Knowledge And Health Practices of parents of children with congenital heart diseases. Archives of Diseases in childhood 1997; 76; 539-40.

14. D B Da Silva, IPR Souza, MCSA Cunha. Knowledge, Attitudes and Status of Oral Health in children at risk for Infective Endocarditis. Int J Ped Dent 2002; 12:124-31.

15. Indira M D, Nandlal B, Narayanappa D, Girish M S. Perception about teething among nursing mothers of Mysore. Journal of International Medicine and Dentistry. 3(2):119-125.

16. Desai M, Messer L B, Calache H. A Study Of The 
ia NG, Dias VO, Oliveira CD, Oliveira MJ. Oral hea 1th of Hospitalized Brazilian Children: A CrossSectional Study. Pesquisa Brasileira em Odontopediatria e Clínica Integrada. 2019;19. e4423

18. Marquezan $\mathrm{M}$, Marquezan $\mathrm{M}$, Pozzobon RT, Oliveira MDM. Medicines used by pediatric dentistry patients and its cariogenic potential. RPG Rev Pós-Grad 2007; 13(4):334-9.

19. Neves BG, Pierro VSS, Maia LC. Perceptions and attitudes among parents and guardians on the use of pediatric medicines and their cariogenic and erosive potential. Ciênc Saúde Coletiva 2007; 12(5): 12951300.
20. Xavier AF, Moura EF, Azevedo WF, Vieira FF, Abreu MH, Cavalcanti AL. Erosive and cariogenicity potential of pediatric drugs: Study of physicochemical parameters BMC Oral Health 2013, 13:71

21. Leal WMS, Lambrecht J, Almeida LS, Rehbein KD, Silva TF, Almeida LHS. Understanding the relationship between medicinal products for pediatric use and dental caries. Rev Pediatr 2015; 15(2):1621

How to cite: MD Indira ,MS Girish, D Narayanappa. Oral Health Status of Hospitalized Children and Parental Perception about Oral Hygiene during Hospitalization: A Cross Sectional Study .Ind J Clin Res Dent 2020;1(2):30-36 